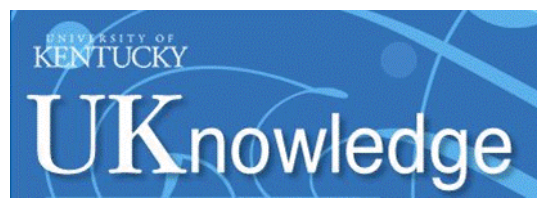

University of Kentucky

UKnowledge

2-2015

\title{
Pregnant, Even When You Did Not Want to Be Pregnant
}

Hatim A. Omar

University of Kentucky, hatim.omar@uky.edu

Joav Merrick

University of Kentucky

Follow this and additional works at: https://uknowledge.uky.edu/pediatrics_facpub

Part of the Pediatrics Commons

Right click to open a feedback form in a new tab to let us know how this document benefits you.

\section{Repository Citation}

Omar, Hatim A. and Merrick, Joav, "Pregnant, Even When You Did Not Want to Be Pregnant" (2015).

Pediatrics Faculty Publications. 189.

https://uknowledge.uky.edu/pediatrics_facpub/189

This Editorial is brought to you for free and open access by the Pediatrics at UKnowledge. It has been accepted for inclusion in Pediatrics Faculty Publications by an authorized administrator of UKnowledge. For more information, please contact UKnowledge@lsv.uky.edu. 


\section{Pregnant, Even When You Did Not Want to Be Pregnant}

Digital Object Identifier (DOI)

http://dx.doi.org/10.1515/ijamh-2014-0044

Notes/Citation Information

Published in International Journal of Adolescent Medicine and Health, v. 27, no. 1, p. 1-2.

The copyright holders have granted the permission for posting the article here. 


\section{Editorial}

Hatim A. Omar and Joav Merrick*

\section{Pregnant, even when you did not want to be pregnant}

DOI 10.1515/ijamh-2014-0044

\section{Introduction}

Pregnancy among adolescents across the world and specifically in the United States continues to be a significant public health concern. The United States leads the developed world in adolescent birth rates, with over 750,000 US adolescents (aged 15-19) becoming pregnant each year (1).

Fortunately, in the last decade, there has been a decline in teen pregnancy. There are multiple reasons for this decline, based on data from the Alan Guttmacher Institute. First, there has been a change in the behavior of sexually experienced teens. Second, in the past two decades, there has been an increase in the percentage of sexually experienced teens who report using a method of contraception during their first sex (2). The reason for the most impact on this decline is that overall contraception use has not only increased, but also more effective methods are available and being utilized. For example, the injectable contraceptive Depo-Provera (depot medroxyprogesterone acetate or DMPA) and the contraceptive implant Norplant (levonorgestrel) were introduced in the early 1990s (3). In 2006, the Food and Drug Administration approved a progesterone-only implant called Implanon (etonogestrel implant) as well as progesterone-containing intrauterine devices (IUDs). These methods have improved the teenager's compliance by removing the responsibility of a daily medication.

Despite this decline, as of 2004, 41.2\% of all pregnancies were in adolescents 15-19 years of age (4). In the United States, $22 \%$ of women report giving birth before the age of 20 years. Compared with other developed countries, Great Britain reports a rate of 15\%; Canada, 11\%; and France, 6\% (5). Despite the higher incidence of adolescent pregnancy in the United States, the sexual activity of teens and the age at onset of first sexual intercourse are consistent across developed countries. In the United States, levels of reported sexual intercourse by adolescents decreased during the 1990s for both sexes after an increase in the previous two decades $(6,7)$. Despite this, a study that was initiated between 1998 and 2001 to investigate adolescent sexuality found that sexually active teens in the United States were less likely to use any contraceptive method and especially less likely to use highly effective hormonal methods than were their peers in other developed countries (3).

\section{Recent trends}

Even in recent years, the United States still has the highest teen birth rate among developed countries, with now approximately 400,000 teens aged 15-19 years giving birth every year in the United States (8). This is a public health concern because teen mothers are more likely to experience negative social outcomes, for example, school dropout (8).

In a recent report, the Centers for Disease Control and Prevention (8) looked at data from the 2004-2008 Pregnancy Risk Assessment Monitoring System (PRAMS) in order to look at the reasons why teens wishing to avoid pregnancy anyway became pregnant.

The PRAMS surveillance collects state-specific, population-based data on maternal attitudes and experiences before, during, and shortly after pregnancy (8). Thirtyseven states and New York City participate in the system, which covers approximately $75 \%$ of all live births in the United States. The PRAMS employs a standardized data collection protocol, sampling women 2-6 months after they deliver a live infant (8).

PRAMS surveys include core questions for all state surveys, plus optional standard and state-developed questions. All respondents were asked the following core questions: "Thinking back to just before you got pregnant with your new baby, how did you feel about becoming pregnant?" Participants who responded "I wanted to be pregnant later" or "I didn't want to be pregnant then or at any time in the future" were classified as having an unintended pregnancy. Participants also were asked, "When you got pregnant with your new baby, were you or your husband or partner doing something to keep from getting 
pregnant?" Participants who reported not doing anything to keep from getting pregnant were then asked, "What were your or your husband's or partner's reasons for not doing anything to keep from getting pregnant?” (8).

The study (8) found estimated rates of self-reported prepregnancy contraceptive use among white, black, and Hispanic teen females aged 15-19 years with unintended pregnancies resulting in live births. Approximately one half $(50.1 \%)$ of these teens were not using any method of birth control when they got pregnant, and of these, nearly one third (31.4\%) believed they could not get pregnant at the time. A total of $21.0 \%$ used a highly effective contraceptive method (although $<1 \%$ used one of the most effective methods, such as an IUD), 24.2\% used the moderately effective method of condoms, and 5.1\% used the least effective methods, such as rhythm and withdrawal.

In summary, teens from 19 states who delivered a live infant from an unintended pregnancy had much lower rates of contraceptive use when compared with all sexually active teens (8). Half of teen mothers in this study did not use any contraception before getting pregnant; this compares with $16.5 \%$ of all sexually active teens reporting that they did not use any method at last sexual intercourse (8). Secondary prevention to decrease repeat teen pregnancy is also crucial, and some have demonstrated success in this area (9).

\section{Conclusions}

Even though the teen pregnancy rate has gone down recently, caring for a pregnant teenager can be challenging. It is crucial to prevent teen pregnancy by implementing appropriate health prevention/promotion policies in a health care setting. A comprehensive contraceptive management approach should also be part of the standard when caring for a teen. Once a pregnancy has occurred, a pregnant teen should be offered a multidisciplinary intervention to help her through the challenging process. This includes her options of keeping/terminating the pregnancy and/or adoption possibilities. Finally, it is very crucial for a health care provider to continue to be part of the care during the teen's pregnancy and postdelivery years to care for the young mother and her child.

\section{References}

1. Alan Guttmacher Institute. US teenage pregnancy statistics: National and state trends and trends by race and ethnicity. New York, NY: Alan Guttmacher Inst, 2006.

2. Darroch J. Why is teenage pregnancy declining? The role of abstinence, sexual activity, and contraceptive use. New York, NY: Alan Guttmacher Inst, 1999.

3. Boonstra H. Teen pregnancy: trends and lessons learned. The Guttmacher report on public policy. Washington, DC: US Department of Health and Human Services, 2002:7-10.

4. Hamilton BE, Martin JA, Ventura SJ, Sutton PD, Menacker F. Births: preliminary data for 2004. Natl Vital Stat Rep 2005;54:1-17.

5. Darroch JE, Singh S, Frost JJ. Differences in teenage pregnancy rates among five developed countries: the roles of sexual activity and contraceptive use. Fam Plann Perspect 2001;33:244-50, 281.

6. National Survey on Drug Use and Health: National findings. Rockville, MD: 2005. Report No. SMA 05-4062.

7. Creinin MD, Burke AE. Methotrexate and misoprostol for early abortion: a multicenter trial. Acceptability. Contracept 1996;54:19-22.

8. Harrison AT, Gavin L, Hastings PA. Prepregnancy contraceptive use among teens with unintended pregnancies resulting in live births. Pregnancy risk assessment monitoring system (PRAMS), 2004-2008. MMWR Morb Mortal Weekly Rep 2012;61:25-9.

9. Omar HA, Fowler A, McClanahan KK. Significant reduction of repeat teen pregnancy in a comprehensive youth parent program. J Pediatr Adolesc Gynecol 2008;21:283-7.

*Corresponding author: Joav Merrick, MD, MMedSci, DMSc, Health Services, Division for Intellectual and Developmental Disabilities, Ministry of Social Affairs and Social Services, PO Box 1260, IL-91012 Jerusalem, Israel, E-mail: jmerrick@zahav.net.il

Hatim A. Omar: Department of Pediatrics, Kentucky Children's Hospital, University of Kentucky College of Medicine, Lexington, KY, USA

Joav Merrick: Department of Pediatrics, Kentucky Children's Hospital, University of Kentucky College of Medicine, Lexington, KY, USA; National Institute of Child Health and Human Development, Jerusalem; Division for Intellectual and Developmental Disabilities, Ministry of Social Affairs and Social Services, Jerusalem, Israel; Division of Pediatrics, Hadassah Hebrew University Medical Center, Mt Scopus Campus, Jerusalem, Israel; and Center for Healthy Development, School of Public Health, Georgia State University, Atlanta, GA, USA 